\title{
Potensi Kerjasama Ekonomi dan Keamanan India-Afghanistan Paska Kemenangan Taliban Tahun 2021
}

\author{
Ida Susilowati*, Muhammad Fauzi, \\ Regga Fajar Hidayat, dan Thoriq Nabeel \\ Universitas Darussalam Gontor \\ *Email: idasusilowati@unida.gontor.ac.id
}

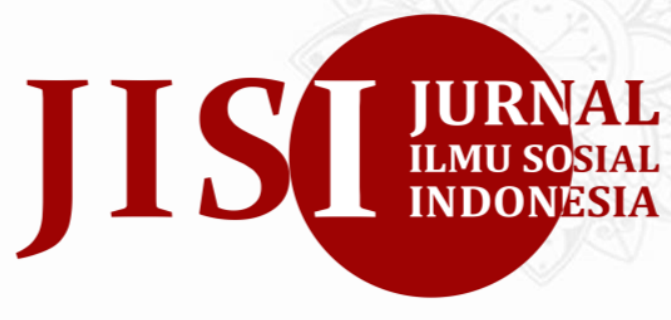

p-ISSN: 2808-9529 (Printed)

e-ISSN: 2808-8816 (Online)

Jurnal Ilmu Sosial Indonesia (JISI)

http://journal.uinjkt.ac.id/index.php/jisi

VOL. 2, NO. 2 (2021)

Page: $106-114$

\section{Recommended Citation:}

Susilowati, I., Fauzi, M., Hidayat, R., \& Nabeel,

T. (2021). Potensi Kerjasama Ekonomi dan

Keamanan India-Afghanistan Paska

Kemenangan Taliban Tahun 2021. Jurnal Ilmu

Sosial Indonesia (JISI), 2(2), 106-114.

doi:https://doi.org/10.15408/jisi.v2i2.24956

Available at:

http://journal.uinjkt.ac.id/index.php/jisi/arti cle/view/24956

Article History:

Received 19 October 2021

Accepted 11 November 2021

Available online 28 December 2021

* Corresponding Author

\begin{abstract}
The internal conflict between the Afghan government and the Taliban has been going on for a long time, and in mid-August 2021 the Taliban succeeded in taking over the Afghan government in Kabul. Various countries began to respond to the event, especially countries that have established diplomatic, economic and military cooperation with Afghanistan, including India. This article aims to analyze the potential for bilateral cooperation in the economic and security fields between India and Afghanistan, especially after the Taliban's success in occupying Kabul and announcing the Afghan government under the Taliban. Qualitative research with descriptive analytical methods is applied in this research, based on data sources obtained through literature study techniques. This research shows that India has the potential to take a policy to continue to cooperate with Afghanistan in the economic and security fields. This due to India's national interest in Afghanistan such as controlling Afghanistan's mineral resources and realizing India as a regional power in the South Asian region.
\end{abstract}

Keywords: National Interest, Bilateral Cooperation, India, Afghanistan, Taliban.

Abstrak. Konflik internal antara pemerintah Afganistan dan Taliban telah berlangsung sejak lama, dan di pertengahan bulan Agustus 2021 Taliban berhasil mengambil alih pemerintahan Afghanistan di Kabul. Berbagai negara mulai merespon peristiwa tersebut, terutama negara-negara yang menjalin kerjasama diplomatik, ekonomi dan militer dengan Afghanistan tidak terkecuali India. Artikel ini bertujuan untuk menganalisis potensi kerjasama bilateral di bidang ekonomi dan keamanan antara India dengan Afganistan, terutama paska keberhasilan Taliban menduduki Kabul dan mengumumkan pemerintahan Afghanistan dibawah Taliban. Penelitian kualitatif dengan metode deskriptif analitis diterapkan dalam penelitian ini, berdasarkan sumber-sumber data yang diperoleh melalui teknik studi pustaka. Penelitian ini menunjukkan bahwa India berpotensi mengambil kebijakan untuk tetap bekerjasama dengan Afghanistan di bidang ekonomi dan keamanan. Hal tersebut tidak terlepas dari kepentingan nasional India terhadap Afghanistan seperti menguasai sumber daya mineral Afganistan dan mewujudkan India sebagai regional power di kawasan Asia Selatan.

Kata Kunci: Kepentingan Nasional, Kerjasama Bilateral, India, Afghanistan, Taliban. 


\section{PENDAHULUAN}

Secara geografis, India dan Afganistan terletak berdekatan dan memiliki keterikatan secara historis dan kebudayaan. Kedua negara tersebut sudah menjalin hubungan bilateral yang baik dimulai sejak akhir Perang Dingin ketika berakhirnya invasi yang dilakukan oleh Uni Soviet di Afganistan. Bagi India, pemerintahan Afganistan yang stabil dan kuat tanpa adanya pengaruh Taliban adalah suatu hal yang sangat diperlukan utntuk keberlangsungan kepentingan nasionalnya. Kepentingan India di Afganistan berpusat untuk mendukung rezim pemerintahan baru dan menutup kemungkinan untuk muncul kembalinya rezim Taliban. Hubungan baik dengan Afganistan adalah salah satu cara untuk mengurangi pengaruh Pakistan terhadap Afganistan (Lone 2013). Dengan tidak adanya peran Pakistan di Afganistan memberikan peluang besar bagi India untuk menguasai sumber daya mineral Afganistan dan mewujudkan India sebagai regional power di kawasan Asia Selatan, juga memberikan pengaruh yang signifikan terhadap kepentingan nasional India (Harsh 2013). Afganistan juga memiliki 0,31 persen dari total export India berupa gula, obat-obatan, pakaian jadi, teh, kopi, rempah-rempah dan menara transmisi (Trading Economics 2020).

Afganistan cukup berperan penting bagi India untuk memperlancar dan mempertahankan hubungan baik antara India, Iran dan negara-negara lainya di kawasan Asia Tengah (Fair 2010). Hal tersebut, mengingat Afganistan sebagai jalur alternatif India untuk mencapai Asia Tengah (Roufbhat 2018). Sementara peranan Iran dan negara Asia Tengah adalah sebagai supply SDA dan mineral untuk menjamin kepentingan nasional di bidang ekonomi dan keamaan energi di negara India (Lone 2013). Selain adanya kepentingan nasional India yang melibatkan Afganistan sebagai peran utama dalam memenuhi kepentingan nasionalnya, peran India di Afganistan adalah untuk mengimbangi kebangkitan Cina, agar Afganistan tidak terpengaruhi oleh Cina (Dutta 2011). Kedua negara saling membahu dalam mempertahankan kedudukan mereka secara geografis. Namun, setelah Taliban berhasil menguasai Kabul pada 15 Agustus 2021 (CNBC Indonesia 2021b), hubungan antara India dan Afganistan mengalami beberapa perubahan kebijakan.

Keberhasilan Taliban menguasai Afganistan pada pertengahan bulan Agustus 2021, menjadi momen bagi India untuk memulai era baru dalam menentukan arah kebijakan ekonomi maupun politik terhadap Afganistan. Strategi-strategi pendekatan lunak India terhadap Afganistan, seperti meresmikan gedung parlemen Afganistan di Kabul sebagai simbol demokrasi baru yang diharapkan
New Delhi dituntaskan sebelum Taliban berkuasa. Kebijakan Pakistan dan Cina yang melakukan pendekatan terhadap rezim Taliban, mengharuskan India untuk menyusun strategi pendekatan baru yang mampu melanggengkan atau mengembalikan pengaruh India di Afganistan. Jika tidak, musuhmusuh India seperti Cina akan mengisi kesenjangan dengan bantuan ekonomi, misalnya mereduksi pengaruh India dan memperluas pengaruhnya dia Asia Tengah (VOA Indonesia 2021).

India perlu meninggalkan pendirian ideologi yang dapat mengancam kepentingannya sendiri, dengan merangkul dan memberi arahan kepada Taliban dengan cara berfikiran terbuka, konstruktif, dan pragmatis yang salah satu caranya adalah mengirim perwakilan khusus sebagai simbol kerjasama dan mengarahkan semua nilai-nilai tersebut (Wong 2021). India hendaknya melakukan pendekatan lunak dan menjadi 'teman' bagi Afganistan di tengah banyaknya kecaman yang ditujukan kepada rezim baru Taliban, sebagai upaya mencapai kepentingan nasional India terhadap Afganistan. Sanksi-sanksi yang dibebankan ke Taliban hanya akan memperburuk keadaan yang dapat berimbas pada kelangsungan hidup masyarakat Afganistan.

\section{METODE}

Penelitian ini bertujuan untuk menganalisis potensi kerjasama ekonomi dan keamanan antara India dan Afganistan di era pemerintahan Taliban, yang mana India selama dua dekade telah berkontribusi banyak bagi Afganistan, baik dalam bidang keamanan maupun ekonomi. Taliban yang berhubungan baik dengan beberapa negara kontra India menjadi dilema tersendiri bagi India.

Isu yang menjadi acuan utama penelitian ini adalah isu baru. Belum banyak penelitian yang mengkaji tentang potensi kerjasama ekonomi dan keamanan India dan Afganistan era pemerintahan Taliban. Dalam hal ini peneliti menemukan satu penelitian yang relevan dengan penelitian saat ini yaitu artikel yang berjudul "India and Post-Taliban Afganistan: Stakes, Opportunities and Challenges" yang ditulis oleh Partha Pratim Basu (Basu 2007). Dalam artikel ini membahas tentang kerja sama dan tantangan India dalam menjalin kerjasama dengan Afganistan pasca kekalahan Taliban. Penelitian tersebut memiliki relevansi dengan penelitian saat ini yaitu dalam bidang kerjasama antara India dan Afganistan. Namun penelitian tersebut lebih membahas potensi kerja sama India dan Afganistan pasca kekalahan Taliban, sementara penelitian ini membahas potensi kerjasama keamanan dan ekonomi India dan Afganistan di era pemerintahan Taliban. 


\section{HASIL DAN DISKUSI}

\section{DINAMIKA KERJASAMA INDIA-AFGANISTAN SEBELUM KENDALI TALIBAN}

Pada tahun 2001, saat runtuhnya rezim Taliban saat itu menjadi titik balik dalam pemulihan hubungan bilateral antara India dan Afganistan. Setelah runtuhnya rezim tersebut, India menggunakan pola strategi yang berbeda dari sebelumnya, yang mana pada beberapa dekade sebelumnya India menggunakan pendekatan hard power seperti halnya membangun kapabilitas militer, intervensi seperti yang dilakukan pada krisis Pakistan tahun 1971 dan konflik etnis Sri Langka tahun 1983-1990. Selain itu, salah satunya adalah sanksi ekonomi seperti halnya blokade ekonomi terhadap Nepal tahun 1989. Namun, setelah runtunya rezim Taliban pada 2001, India menggunakan pendekatan soft power guna untuk menguatkan perannya di Afganistan dengan bertindak lebih kooperatif untuk meningkatkan daya tarik dan kredibilitas. Pendekatan soft power tersebut melalui 3 hal, yaitu; (a) Bantuan luar negeri berupa bantuan kemanusiaan dan investasi dalam bidang infrastruktur, (b) Program perdagangan untuk membantu kestabilan perekonomian Afganistan, dan (c) Promosi kebudayaan sebagai bentuk penguatan diplomasi publik India (John 2011).

Pada bulan Maret 2003, India dan Afganistan menandatangani Preferential Trade Agreement (PTA) di mana India memberikan konsesi bea masuk yang substansial mulai dari 50\% hingga $100 \%$ untuk kategori tertentu, sepert jenis buah kering dari Afganistan. Pada gilirannya, Afganistan telah memberikan konsesi timbal balik untuk produk-produk India seperti teh, gula, semen, dan obat-obatan. Pada KTT SAARC di Male pada bulan November 2011, India menghapus bea masuk dasar untuk semua LDC SAARC, memungkinkan semua produk Afganistan (kecuali alkohol dan tembakau) akses bebas bea ke pasar India (Indian Trade Portal 2015).

Pada tahun 2015, Perdana Menteri Narendra Modi meresmikan gedung Parlemen Afganistan yang baru, yang dibangun oleh India dengan biaya \$90 juta, Narendra Modi mengatakan ini merupakan penggambaran sebuah penghargaan dari negaranya terhadap demokrasi di Afganistan. Pada tahun berikutnya, Perdana Menteri Narendra Modi Memberikan dana untuk renovasi Istana Stor abad ke-19 yang terletak di Kabul, yang merupakan rumah bagi Raja Afganistan Amanullah Khan selama pemerintahannya pada tahun 1920 -an. Pada tahun 2016, Perdana Menteri Narendra Modi meresmikan Bendungan Salma, sebuah proyek infrastruktur penting di kota barat Herat yang memungkinkan akses air ke distrik-distrik sekitarnya dan irigasi ribuan hektar lahan. Dengan investasinya di proyek jalan raya dan bangunan lainnya, secara total, India telah memasukkan sekitar \$3 miliar ke Afganistan, menjadikannya salah satu donor regional terbesar ke negara itu (Ananta 2021).

Sebelum Taliban berkuasa di Afganistan, India telah menjalin hubungan kerjasama ekonomi berupa ekspor-impor yang cukup erat. Menurut Kedutaan Besar India di Afganistan (Embassy of India in Kabul 2021), pada 2019-2020 perdagangan bilateral antara India dan Afganistan menuju angka USD 1,5 miliar. Ekspor India ke Afganistan hampir mencapai 1 miliar dolar AS (997,58 juta dolar AS) dan 530 juta dolar AS impor India dari Afganistan. Dalam lima tahun terakhir, peningkatan nilai komersial terus meningkat. Ekspor India ke Afganistan telah menunjukkan peningkatan hampir 89 persen antara 2015-2016 dan 2019-2020, sebagai perbandingan. Demikian pula pada periode yang sama, impor India juga meningkat sebesar 72\%. Pada 2019-2020, nilai ekspor naik 39\% dibandingkan dengan impor pada 2018-2019 lebih dari $21 \%$.

Pada Desember 2020 India mengirim banyak senjata ke Afganistan guna membantu memerangi milisi dan ekstremis di negara tersebut. Namun ini menjadi sebuah kekhawatiran besar bagi Pakistan mengingat kerja sama yang semakin erat diantara kedua negara tersebut yang terletak disamping timur dan barat. Kurang lebih US\$ 2 miliar (Rp 26,4 triliun) sebagai bantuan ekonomi kepada Afganistan sejak 15 tahun lalu. Namun New Delhi membatasi pasokan senjata untuk menghindari reaksi Pakistan, yang melihat Afganistan sebagai wilayah pengaruhnya. Pada Desember 2020 India mengirimkan 4 helikopter tempur kepada india dan ini merupakan pengiriman alat perang pertama sejak Taliban digulingkan, disamping itu kekhawatiran Pakistan semakin membesar. Selain itu pada pertemuan Menlu AS Antony Blinken dan PM India Narendra Modi pada Rabu 28 Agustus 2021, India juga mengajak Amerika untuk memperkuat militer Afganistan untuk menggulingkan Taliban (Gail 2021).

Salah satu proyek profit tinggi lainnya adalah jalan raya Zaranj-Delaram sepanjang $218 \mathrm{~km}$ yang dibangun oleh Organisasi Jalan Perbatasan. Zaranj terletak dekat perbatasan Afganistan dengan Iran. Jalan raya senilai 150 juta USD ini membentang di sepanjang sungai Khash Rud ke Delaram di timur laut Zaranj, di mana ia menghubungkan ke jalan lingkar yang menghubungkan Kandahar di selatan, Ghazni dan Kabul di timur, Mazar-i-Sharif di utara, dan Herat di barat (D'Souza 2007).

Taliban dan India mempunyai sejarah yang kurang berkenan di hati masyarakatnya, terutama bagi kelompok Taliban ketika India membantu tentara asing yang termasuk didalamnya NATO 
menginvasi Afganistas saat masa kependudukan Taliban di negeri itu. Taliban juga sering dikaitkan dengan terorisme yang acap kali mengancam keamanan India terutama diwilayah perbatasan. Maka, tidak berlebihan jika India mempunyai pandangan skeptis dan hati-hati terhadap gerakgerik Taliban. Perbedaan latar belakang kepercayaan juga menjadi alasan ketidakakuran mereka. Ditambah dengan dekatnya kelompok ini dengan Pakistan yang merupakan musuh bebuyutan India.

\section{KEPENTINGAN NASIONAL SEBAGAI INSTRUMEN KEBIJAKAN LUAR NEGERI}

Kepentingan nasional dalam ungkapan Perancis disebut raison d'État yang dapat dimaknai dengan tujuan dan ambisi suatu negara dari segi ekonomi, militer, atau budaya. Konsep ini adalah konsep dasar dalam Hubungan Internasional jika merujuk kepada aliran arus utama (Bainus 2018). Dalam melihat potensi-potensi kerjasama yang akan dijalankan India dengan Afganistan, peneliti dapat melihat dari kepentingan nasional India terhadap negara tersebut. Kepentingan nasional sangatlah penting bagi suatu negara untuk mencapai kebutuhannya seperti apa yang dijelaskan melalui konsep kepentingan nasional (Harini 2012).

Merujuk kepada gagasan yang disampaikan Daniel S. Papp tentang kepentingan nasional, bahwa dalam kepentingan nasional terdapat beberapa aspek, seperti ekonomi, ideologi, kekuatan dan keamanan militer, moralitas dan legalitas. Dalam hal ini, faktor ekonomi pada setiap kebijakan yang diambil oleh suatu negara diprioritaskan untuk meningkatkan perekonomian bersama. Bagian inilah yang sering dinilai sebagai suatu kepentingan nasional (Papp 1988). Begitupun terkait kerjasama bilateral antara India dengan pemerintahan Taliban di Afganistan.

Kepentingan nasional dapat dipahami sebagai konsep kunci dalam politik luar negeri. Konsep tersebut mengarah kepada ideologi suatu negara ataupun pada sistem nilai sebagai pedoman perilaku suatu negara terhadap negara lain. Dapat diartikan bahwa keputusan dan tindakan politik luar negeri suatu negara bisa didasarkan pada pertimbangan-pertimbangan ideologis ataupun dapat terjadi atas dasar pertimbangan kepentingan ekonomi. Namun bisa juga terjadinya interplay antara ideologi dengan kepentingan ekonomi, sehingga terjalin hubungan timbal balik dan saling mempengaruhi antara pertimbangan-pertimbangan ideologis dengan kepentingan ekonomi yang tidak menutupi kemungkinan terciptanya sebuah kebijaksanaan politik luar negeri yang lain atau baru.
Korelasi kepentingan nasional dengan kebijakan luar negeri cukup erat, karena adanya kepentingan nasional suatu negara, bisa mempengaruhi terciptanya suatu kebijakan luar negeri yang bertujuan untuk memenuhi kepentingan-kepentingan negara tersebut (Saputra 1985). Selaras dengan itu, Paul Seabury menyatakan (Clinton 1986) bahwa Ide kepentingan nasional mungkin menyatu pada serangkaian tujuan ideal yang seharusnya diusahakan untuk diwujudkan oleh suatu bangsa dalam tindakan hubungan luar negerinya, kepentingan nasional dapat dianggap sebagai tujuan yang ingin dicapai melalui kepemimpinan dengan perjuangan yang gigih.

\section{KEPENTINGAN EKONOMI INDIA DALAM KERJASAMA BILATERAL DENGAN AFGANISTAN}

Adanya krisis geo-politik yang sedang berlangsung di Afganistan, memberikan dampak pada kegiatan jual-beli antar negara. Salah satunya antara India dan Aghanistan yang biasanya melakukan transaksi untuk penjualan buah-buahan kering dan rempah-rempah. Pada transaksi tersebut India mengenakan bea masuk yang lebih rendah dari produk yang di impor dari Afganistan. Jadi, pedagang yang berasal dai India dapat mengimpor barang-barang tersebut dari Afganistan dengan pasokan jangka panjang.

Kembalinya rezim Taliban di Afganistan, telah menyegel dua terminal penting untuk perdagangan melalui daratan yang berada di perbatasan Pakistan-Afganistan. Para pedagang harus mencari tujuan lain untuk mengimpor barang-barang tersebut, sehingga pada akhirnya dapat menimbulkan naiknya harga domestik. Salah satu alasan India bertransaksi dengan Afganistan adalah karena barang-barang yang di impor dari Afganistan tidak tersedia di tempat lain dan harga yang relatif tinggi. Berbeda dengan pembelian barang dari Afganistan, India dapat mengimpor bebas bea di bawah Area Perdagangan Bebas Asia selatan atau South Asian Free Trade Area (SAFTA).

Pada tahun 2020 India mengumumkan 150 proyek baru di Afganistan senilai 80 juta USD. Pemerintah India juga menginvestsikan lebih dari USD 3 miliar sekitar Rp 42,8 triliun dalam proyek pembangunan di Afganistan (FINSHOTS 2021). Hal tersebut dapat menjadi alasan kuat bagi India untuk terus bekerjasama dengan Afganistan meskipun dibawah kendali rezim Taliban. India juga kehilangan kesempatan emas dalam mendapat keuntungan dari tambang emas Hajigak di distrik Bamyan yang dinilai seharga 11 miliar USD. Kebutuhan India terhadap akses penghubung perdagangan India ke pelabuhan Chabahar di Iran, turut menjadi faktor bagi India untuk melewati Pakistan dan mengakses perdagangan global. 
Pelabuhan Chabahar dinilai penting bagi India untuk menghadapi ekspansi pengaruh China di wilayah Samudera Hindia (Hindustan Times 2016).

Akses perdagangan dari pelabuhan Chabahar nantinya akan terakses secara langsung dengan Zaranj di Afganistan. Jalur ini bisa menyambungkan jalan Zaranj-Delaram sepanjang $218 \mathrm{~km}$ yang pembangunannya ditangani langsung oleh pemerintahan India pada tahun 2009 (Wani, Mir, and Akhter 2017). Jalur tersebut akan berakhir hingga jalan raya Garland. Karena itu, India perlu bekerjasama dengan Afganistan untuk dapat mengambil pelajaran dari strategi One Belt One Road (OBOR) yang dilakukan pemerintahan China (Guo et al. 2019). Berawal dari negara-negara tetangga ataupun lingkup regional, India mampu menciptakan jalur sutera bagi perdagangan India sendiri.

Tentunya dalam mencapai kepentingan ekonomi nasionalnya, India mempunyai rival yang mengancam kelangsungan potensi kerjasama terutama dalam bidang perdagangan dengan Afganistan. Menurut Badan Otoritas Informasi dan Statistik Nasional Afganistan, tiga mitra dagang terbesar Afganistan adalah; Iran, Pakistan dan China.Detik News. 2021. "Taliban Dorong China Berinvestasi Di Afghanistan, Tapi Itu Bukan Hal Mudah". Diakses dari https://news.detik.com/abcaustralia/d-5702328/taliban-dorong-china-

berinvestasi-di-afghanistan-tapi-itu-bukan-halmudah/, pada 12 Oktober 2021 (09:45). Antara tahun 2019 dan 2020, nilai ekspor Afganistan ke China berada di kisaran Rp770 miliar, sementara impor dari China bernilai sekitar Rp1,37 triliun. Meski perdagangan bilateral masih kecil, investasi langsung China ke Afganistan meningkat 11 persen di tahun 2020 (ABC News 2021). Banyak perusahaan-perusahaan Cina yang beranggapan bahwa saat ini, yaitu paska datangnya Taliban adalah waktu yang tepat untuk memperluas pasar dan mempererat kerjasama dengan Afganistan.

Pertemuan Menteri Luar Negeri China Wang Yi dengan delegasi dengan Taliban di Tianjin, mengindikasikan adanya proses kerjasama yang lebih intens antara kedua pihak (China Briefing 2021). Kerjasama dalam bidang ekonomi meliputi infrastuktur, ekonomi, dan investasi. Hal-hal ini tentunya akan mengganggu stabilitas kerjasama dalam bidang ekonomi, saat India mulai menentukan sikap untuk bekerjasama dengan Afganistan dan tidak mengusik masalah internal yang terjadi di negara tersebut. Ancaman ini semakin besar, mengingat semakin kuatnya kerjasama China dan Pakistan yang merupakan musuh India.

\section{KEPENTINGAN KEAMANAN INDIA DALAM KERJASAMA BILATERAL DENGAN AFGANISTAN}

India memiliki beberapa kepentingan nasional di bidang keamanan yang dapat berjalan atau lebih mendekati keberhasilan jika dengan bekerjasama dengan Afganistan di masa permerintahan rezim Taliban. Salah satunya adalah kerjasama dalam rangka mengurangi pengaruh Cina di kawasan tersebut. India dan Cina masih memliki masalah yang semakin berkembang satu tahu terakhir, yang paling menonjol adalah masalah perbatasan (CNN Indonesia 2020). Dari masalah yang muncul dari isu perbatasan tersebut, India melakukan pemblokiran terhadap sekitar 200 aplikasi asal Tiongkok. Ditambah, kedua negara terus berlomba dalam hal infrastruktur di sekitar wilayah sengketa di perbatasan Himalaya (BBC Indonesia 2020).

Faktanya memang secara geografis Afganistan tidak terlibat langsung dengan permasalahan wilayah yang terjadi antara Tiongkok dan India. Namun India bisa membujuk Afganistan dalam mendukung pengaruhnya di wilayah sengketa tersebut yang juga mengancam keamanan perbatasan India. India bisa saja membujuk Afganistan agar mengintervensi kebijakan Cina yang mempunyai beberapa kepentingan nasional dengan Afganistan. Namun, pada akhirnya semua itu tergantung dari seberapa besar keuntungan yang didapat Afganistan dari India.

Setelah munculnya kembali rezim Taliban pada tahun 2021, Pakistan mempunyai banyak kesempatan dalam memanfaatkan celah yang ada untuk menyeranag India (Coudhury 2001) Potensi tindakan yang akan dilakukan Pakistan tersebut merujuk kepada sejarah saat kekuasaan terakhir Taliban di tahun 2001, mereka melindungi gerilyawan pro Pakistan yang merupakan musuh utama dan acaman bagi India. Maka dari itu, dapat diasumsikan bahwa Pakistan memiliki keyakinan bahwa kembalinya rezim Taliban ini akan mendukung Pakistan dalam upaya-upaya penyerangan terhadap India, yang salah satu tujuanya adalah menyengketa wilayah Kashmir. Konflik Kashmir adalah persengketaan wilayah antara pemerintah India, gerilyawan Kashmir dan Pemerintah Pakistan dalam merebut kendali atas wilayah Kashmir (Mohan 1992).

Dengan adanya isu tentang rencana penyerangan Pakistan terhadap India, maka dapat memunculkan kekhawatiran bagi India akan terjadinya integrasi kekuatan Pakistan dan Taliban, yang besar kemungkinan dapat meluluhlantakkan pertahanan India. Dari sini dapat dipahami, pentingnya bagi India untuk menentukan kepentingan nasionalnya di bidang keamanan terhadap Afganistan. Jika hal ini tidak terjadi, dan 
hubungan India dan Afganistan tidak mengalami perubahan yang positif, maka kemungkinankemungkinan buruk tersebut semakin berpotensi untuk terjadi. India juga akan terancam tertinggal dengan negara-negara lain yang sudah mulai menunjukkan respon positif terhadap rezim Taliban.

\section{POTENSI KERJASAMA INDIA-AFGANISTAN ERA PEMERINTAHAN TALIBAN DI AFGANISTAN}

Merujuk kepada Kalevi Jaakko Holsti tentang konsep kepentingan nasional, ia mendefinisikan bahwa kepentingan nasional secara minimum, mencakup keutuhan wilayah suatu bangsa, kemerdekaan dan kelangsungan hidup nasional. Namun kelangsungan hidup nasional itu sendiri diberi bermacam-macam interpretasi oleh bermacam-macam negara yang menghadapi kondisi yang berlain-lainan tersebut. Menurut Holsti, kepentingan nasional itu dapat diklasifikasikan kedalam tiga klasifikasi. Pertama, core values, sesuatu yang dianggap paling vital bagi negara dan menyangkut eksistensi suatu negara. Kedua, middle range objectives, biasanya menyangkut tentang peningkatan derajat perekonomian suatu negara, dan yang ketiga adalah long range goals yaitu yang bersifat ideal misalnya, keinginan untuk mewujudkan perdamaian dan ketertiban dunia (Holsti 1970).

Selain itu, Thomas Hobbes memandang bahwa negara dipandang sebagai pelindung wilayah, penduduk, dan cara hidup yang khas dan berharga. Ia menyimpulkan demikian karena menurutnya negara merupakan sesuatu yang esensial bagi kehidupan warga negaranya (Schmitt 2008). Di lain sisi, Wolfers mengungkapkan bahwa cakupan kepentingan nasional meliputi keutuhan wilayah suatu bangsa, kemerdekaan, dan kelangsungan hidup nasional. Namun, kelangsungan hidup nasional itu sendiri diberi beragam interprestasi oleh macam -macam negara yang menghadapi kondisi yang berbeda satu sama lain. Morgenthau juga mengemukakan, bahwa kepentingan nasional yang sebenarnya bagi suatu bangsa merupakan kenyataan obyektif yang bisa digambarkan dan para peneliti dapat membuat outline tentang kenyataan itu, para pengamat maupun peneliti bisa menggunakan konsep kepentingan nasional tersebut sebagai pengukur sesuai atau tidaknya, maupun benar atau tidaknya politik luar negeri yang dijalankan negara tersebut (Mardhatillah and Umar 2017).

Kebijakan hukum dan politik suatu negara sangat berpengaruh bagi pembangunan ekonomi yang menjadi fokus tujuan suatu negara. Yang nantinya, bentuk kebijakan negara tersebut efektif dan condong mendukung rencana pembangunan ekonomi negara yang menjadi tujuan utama dalam kepentingan nasionalnya. Semakin besar peran politik terhadap pembangunan ekonomi, akan semakin besar pula dampak kemungkinan tercapainya rencana pembangunan ekonomi negara tersebut (Riswandi 2004). Hukum yang telah dirancang, diniatkan untuk melindungi suatu kepentingan dengan melakukan alokasi kekuasaan melalui kekuatan hukum tersebut agar lebih leluasa dalam mencapai kepentingannya. Pengalokasian kekuasaan ini dilakukan secara terukur, dalam artian ditujukan untuk benar-benar agar tercapai tujuan kepentingannya namun tidak melukai esensi dari fungsi hukum tersebut. Dalam kata lain, kekuasaan yang dimaksud demikian bisa disebut dengan hak (Rahardjo 1982). Dengan demikian, pemerintah India dengan alasan kepentingan nasionalnya di bidang ekonomi dengan Afganistan, dapat membuat regulasi yang lebih terbuka terhadap keberadaan Taliban di Afganistan.

Dalam hal ini India memilki banyak aspek vital yang berkaitan dengan peningkatan ekonominya, mengingat investasi India yang cukup besar bagi Afganistan sebelum era pemerintahan Taliban, diantaranya pembangunan gedung parlemen Afganistan yang baru pada tahun 2015 dengan total biaya $\$ 90$ juta dan salah satu proyek profit tinggi adalah jalan raya Zaranj-Delaram sepanjang $218 \mathrm{~km}$ yang menghabiskan dana $\$ 150$ juta (Ananta 2021). Dengan melihat investasi India di Afganistan sebelum era pemerintahan Taliban yang direncanakan sebagai aspek peningkatan ekonomi bagi India, akan terbuang sia-sia jika India tidak menjalin hubungan baik dengan Taliban.

Dengan besarnya investasi India $\mathrm{di}$ Afganistan sebelum era pemerintahan Taliban maka akan memicu potensi kerja sama anatar India dan Taliban pada saat ini, dengan kata lain India tidak ingin membuang investasinya secara sia-sia, meskipun India harus berdempetan dengan Pakistan yang notabene dua negara ini memilki hubungan yang kurang baik, tentunya tidak akan menjadi penghalang untuk melanjutkan kepentingan nasional di Afganistan walaupun dalam keadaan di bawah kendali rezim Taliban (Kurniawan 2021b).

Taliban menjamin keamanan bagi agama minoritas, termasuk umat Sikh dan Hindu yang merupakan pemeluk agama mayoritas bagi masyarakat India. Runtuhnya pemerintahan sipil Afganistan tidak membuat pemeluk agama selain Islam dalam bahaya, meski takut adanya ancaman ataupun diskriminasi. Mereka juga takut kembali ke era di mana mereka dipaksa memakai turban kuning untuk menunjukkan status non-muslim mereka. Warga Afganistan dari lintas agama juga dijanjikan suaka oleh pemereintah di New Delhi yang membuat mereka merasa lebih aman walupun 
di bawah kepemimpinan kelompok Taliban (Republika 2021b). Hal ini dapat memicu terjadinya kerjasama yang lebih luas lagi antara Taliban dan pemerintah India, karena terjalinnya toleransi identitas diantara keduanya. Ditinjau dari pendekatan konstruktivisme kerjasama tersebut dapat terwujud, karena Hubungan Internasional adalah hasil daripada konstruksi masyarakat yang menjadi acuan langkah suatu negara (Jackson 2002).

Isu keamanan dapat menjadi salah satu kerjasama yang dapat menjadi salah satu fokus. Taliban dan India menghadapi ancaman yang sama dengan kehadiran ISIS (Republika 2021a). Salah satu aksinya adalah bom bunuh diri yang terjadi di dekat Bandara Internasional Hamid Karzai yang menargetkan warga sipil dan beberapa personel Taliban (Varshalomidze 2021). India juga mempunyai sejarah konflik dengan ISIS. Pada tahun 2016 ISIS mengusik keharmonisan yang dibangun oleh umat Islam dan Hindu di India yang menyembah pohon, sapi, dan matahari (Republika 2016). Mereka mengejek dan bahkan memaksa umat Islam untuk pindah ke wilayah mereka. Sudah sewajarnya jika kedua belah pihak menguatkan hubungan dalam segi keamanan guna mencegah segala ancaman terutama dari ancaman teroris ISIS, seperti kerjasama yang dibentuk Filipina dan Amerika Serikat dalam menanggulangi ancaman teroris Abu Sayyaf (AsSakir 2017).

Saat rezim Taliban terakhir berkuasa, pemerintah India bersama Rusia dan Iran mendukung aliansi utara untuk melakukakn perlawaan bersenjata terhadap Taliban guna untuk meruntuhkan rezim tersebut, yang akhirnya rezim Taliban tersebut runtuh pada tahun 2001. Setelah runtuhnya rezim Taliban pada 2001 pemerintah India mendapatkan keuntungan dari adanya sebuah investasi yang berjalan di Afganistan. Contohnya pada tahun 2020 India mengumumkan 150 proyek baru di Afganistan senilai 80 juta USD. Pemerintah India juga telah menginvestsikan lebih dari USD 3 miliar atau sekitar Rp 42,8 triliun dalam proyek pembangunan di Afgnistan (CNBC Indonesia 2021a).

Pemeritah India tidak ingin mengalami kerugian atas investasi bisnis yang meraka lakukan di Afganistan. Hal tersebut menjadi alasan mengapa kerjasama bidang investasi antara kedua kelompok dapat terjalin baik. Jika India melanjutkan perlawanan senjata seperti dulu, maka investasi yang sudah dilakunya menjadi sia-sia. Sebaliknya, jika India berkerja sama dengan Taliban, India bisa mendapatkan peluang berinvestasi lebih banyak dan akan mendapatkan keuntungan yang banyak juga sehingga sebuah kepentingan nasional India terpenuhi. Oleh sebab itu, india ingin melanjutkan kerjasama tersebut dengan membubarkan atau menghentikan perlawanan bersenjata yang dulu dilakukanya pada tahun 1996-2001.

\section{KESIMPULAN}

Sejak kedatangan Taliban yang kedua pada 15 Agustus 2021, langkah politik India haruslah lebih berfikir tentang potensi-potensi keuntungan yang simbiolis jika menjalin hubungan baik dengan rezim baru di negara yang tadinya menjadi objek ekspor, ladang investasi, serta rekan dalam beberapa kebijakan yang menyangkut kawasan regional mereka. Pendekatan ini sudah dimulai sejak datangnya perwakilan India kepada kantor Taliban yang bertempat di Qatar, yang bisa menjadi sumbu awal dari kerjasama mereka. Ditambah dengan janji Taliban yang akan melindungi warga negara dan penganut agama lain yang tinggal di Afganistan, termasuk warga negara India dan umat Hindu.

Dengan keadaan yang memungkinkan seperti ini, sudah sewajarnya jika kedua belah pihak tidak mempermasalahkan masalah yang menyangkut politik dan kebencian lainnya yang terbawa oleh masa lalu. Waktunya untuk mempersiapkan segala kemungkinan untuk menghadapi masa depan demi kelangsungan kedua belah pihak. Menjalankan kegiatan ekspor-impor, menghidupkan investas, melakukan kerjasama keamanan hingga latihan militer bersama, hal itu semua dapat dilakukan mengingat kedua belah pihak juga memiliki musuh yang sama yaitu ISIS. Dengan kerjasama kedua belah pihak, kawasan regional mereka juga semakin aman dari ancaman Cina yang walaupun berupaya baik dalam mendukung Taliban, namun sangat berbahaya jika mereka menjalankan kolonialisasi gaya baru di kawasan yang kaya akan sumber daya alam tersebut.

\section{DAFTAR PUSTAKA}

ABC News. 2021. "The Taliban is persuading China to invest in Afghanistan, but it is not an easy task". Diakses dari https://www.abc.net.au/news/2021-0829/the-taliban-trying-to-persuade-china-toinvest-in-afghanistan/100408696, pada 12 Oktober (09:59).

Ananta, Z. 2021. "India Tingkatkan Kerja Sama Militer dengan Afganistan". Diakses dari https://dunia.tempo.co/read/798250/india -tingkatkan-kerja-sama-militer-denganafganistan, pada 10 Oktober 2021 (22.02).

Ananta, Z. 2021."India Tingkatkan Kerja Sama Militer dengan Afganistan". Diakses dari https://dunia.tempo.co/read/798250/india -tingkatkan-kerja-sama-militer-denganafganistan, pada 17 Oktober 2021 (21.04). 
AsSakir, Aulia. 2017. “Kerjasama Antara Pemerintahan Amerika Serikat dan Filipina dalam Memberantas Abu Sayyaf Group di Filipina Selatan" pada Islamic World and Politics. Vol. 1, No. 1.

Bainus, Arry. 2018. "Kepentingan Nasional dalam Hubungan Internasional." pada Intermestic: Journal of International Studies. Vol. 2, No.2.

Basu, P. P. 2007. "India and post-Taliban Afghanistan: Stakes, opportunities and challenges" pada India Quarterly, Vol. 63, No. 3.

BBC Indonesia. 2020. "Konflik China-India: Dua Rival Berlomba Bangun Infrastruktur di Perbatasan Himalaya yang Menjadi Sengketa". Diakses dari https://www.bbc.com/indonesia/dunia53576502, pada 18 September 2021 (12.55).

China Briefing. 2021. "China and Afghanistan: Bilateral Trade Relationship and Future Outlook". Diakses dari https://www.chinabriefing.com/news/china-and-afghanistanbilateral-trade-relationship-and-futureoutlook/, pada 12 Oktober 2021 (10:44).

Clinton, W. David. 1986. "The national interest: normative foundations." pada The Review of Politics. Vol. 48, No. 4.

CNBC Indonesia. 2021. "Pepet Taliban, Apa Sebetulnya Niat Xi Jinping di Afghanistan?". Diakses dari https://www.cnbcindonesia.com/news/202 10811174510-4-267789/pepet-taliban-apasebetulnya-niat-xi-jinping-di-afghanistan/2, pada 17 Oktober 2021 (21.22).

CNBC Indonesia. 2021. "Taliban Menang di Afganistan, Kabul Resmi Dikuasai”. Diakses dari

https://www.cnbcindonesia.com/news/202 10816063206-4-268604/taliban-menangdi-afganistan-kabul-resmi-dikuasai, pada 12 September 2021 (20.41).

CNN Indonesia. 2020. "Konflik China-India, dari Perbatasan hingga Perang Teknologi". Diakses dari https://www.cnnindonesia.com/internasion al/20201126123141-113-574800/konflikchina-india-dari-perbatasan-hingga-perangteknologi, pada 18 September 2021 (12.51).

Detik News. 2021. "Taliban Dorong China Berinvestasi Di Afghanistan, Tapi Itu Bukan Hal Mudah". Diakses dari https://news.detik.com/abc-australia/d5702328/taliban-dorong-chinaberinvestasi-di-afghanistan-tapi-itu-bukanhal-mudah/, pada 12 Oktober 2021 (09:45).

D'Souza, S. M. 2007. "India's aid to Afghanistan: Challenges and prospects" pada Strategic Analysis. Vol. 31, No. 5.
Dutta, Sujit. 2011. "Managing and Engaging Rising China:India's Evolving Posture" pada Washington Quarterly. Vol. 34, No. 2.

Embassy of India in Kabul. 2021. "India-Afghanistan Commercial Brief". Diakses dari https://eoi.gov.in/kabul/?11360?000, pada 12 September 2021 (20.01).

Fair, C. Christine. 2010. India in Afghnistan and Beyond: Opportunities and Constraints. New York: A Century Foundation Report.

FINSHOTS. 2021. "Why did India invest up to $\$ 3 B n$ in Afghanistan". Diakses dari https://finshots.in/archive/why-did-indiainvest-up-to-3bn-in-afghanistan/, pada 11 Oktober 2021 (08:42).

Gail, J. 2021. "Will India's Investments In Afganistan Amount to Anything". Diakses dari https://www.livemint.com/news/india/will -india-s-investments-in-afghanistanamount-to-anything-11630281437354.html, pada 12 September 2021 (2019).

Guo, C., Lu, C., Andreevich, D. D., \& Jielin, Z. 2019. "Implications of "One Belt, One Road" Strategy for China and Eurasia" pada Вестник Российского университета дружбы народов. Серия: Международные отношения. Vol 19, No 1.

Harini, S. 2012. "Kepentingan Nasional China Dalam Konflik Laut Cina Selatan" pada Transformasi. Vol. 14, No. 21.

Hindustan Times. 2016. "India-Iran-Afghanistan sign Chabahar port Agreement". Diakses dari https://www.hindustantimes.com/india/ind ia-iran-afghanistan-sign-chabahar-portagreement/, pada 11 Oktober 2021 (11:10).

Holsti, Kalevi J. 1970. "National role conceptions in the study of foreign policy." International studies quarterly. Vol. 14, No. 3.

Indian Trade Portal. 2015. "Preferential Trade Agreement Between India And Afghanistan (PTA)". Diakses dari https://www.indiantradeportal.in/vs.jsp?la ng=0\&id $=0,1,63,70$, pada 10 Oktober 2021 (21.46).

Jackson, Patrick. 2002. "Whence Causal Mechanisms? A Comment on Legro" pada Dialogue IO. Vol. 1.

John, D. Ciorciari. 2011. "India's Approach to Great Power Status" pada the Fletcher Forum of World Affairs, Vol.35 No. 1.

Kurniawan, Indra. 2021. “Ga Mau Rugi, India Bersiap Lanjutkan Kerjasama Dengan Afghanistan Meski Taliban Berkuasa,". Diakses dari https://prfmnews.pikiranrakyat.com/internasional/pr132507195/ga-mau-rugi-india-bersiaplanjutkan-kerjasama-dengan-afghanistan- 
meski-taliban-berkuasa, pada 12 Oktober 2021 (13:12).

Lone, Raheel Majeed. 2013. "Indo-Afghan Relations After September 11: Implications For Pakistan" pada IOSR Journal of Humanities and Social Science, Vol. 15, No. 3.

Mardhatillah , Ahmad Rizky Umar. 2017. "The National Interest in International Relations Theory," pada Global South Review. Vol. 1, No. 2.

Mohan, A. 1992. "The historical roots of the Kashmir conflict"pada Studies in Conflict \& Terrorism, Vol. 15, No. 4.

Pant, Harsh V. 2013. "India in Afganistan: A Test Case For a Rising Power" pada Contemporary South Asia. Vol. 18, No. 2.

Papp, Daniel S. 1988. Contemporary International Relations: A Framework for Understanding. Edisi Kedua, New York: MacMillan Publishing Company.

Rahardjo, Satjipto. 1982. Ilmu Hukum. Bandung: Alumni.

Republika. 2016. "ISIS Ancam Lakukan Serangan di India". Diakses dari https://www.republika.co.id/berita/o7jfqc3 28/isis-ancam-lakukan-serangan-di-india, pada 12 September 2021 (21:16).

Republika. 2021. "Biden Akui ISIS Merupakan Musuh Bebuyuran Taliban". Diakses dari https://www.republika.co.id/berita/qyagwx 377/biden-akui-isis-merupakan-musuhbebuyutan-taliban, pada 12 September 2021 (21:14).

Republika. 2021. "Nasib Umat Sikh dan Hindu Afganistan di Bawah Taliban". Diakses dari https://republika.co.id/berita/qz6ss815150 00/nasib-umat-sikh-dan-hindu-afganistandi-bawah-taliban pada 11 September 2021 (13.54).

Riswandi, Budi Agus. 2004. "Politik Hukum Hak Cipta: Meletakkan Kepentingan Nasional Untuk Tujuan Global" pada Jurnal Hukum. Vol. 11, No. 25.

Roufbhat, Abdul. 2018. "Afganistan Factor in IndiaCentral Asia Relations" pada International Journal of Research in Social Science. Vol. 8.

Sahely Roy Coudhury. 2001. "From India to China, the Taliban's Return Leaves Afghanistan's Neighbors Scrambling to Adjust". Diakses dari https://www.cnbc.com/2021/08/18/afgha nistan-taliban-impact-on-pakistan-indiachina-russia-iran.html, pada 18 September 2021 (13.10).

Saputra, Sumpena Prawira, 1985. Politik Luar Negeri Indonesia. Jakarta: Remaja Karya Offset.
Schmitt, C. 2008. The Leviathan in the state theory of Thomas Hobbes: meaning and failure of a political symbol. University of Chicago Press

Trading Economics. 2020. "India Exports By Country". Diakses dari https://tradingeconomics.com/india/export s-by-country, pada 12 September 2021 (20.32).

Varshalomidze, Tamila. 2021. "Civilians, US Troops among Dozens Killed in Kabul Blasts". Diakses dari https://www.aljazeera.com/news/2021/8/ 26/panic-grips-kabul-airport-as-evacuationdeadline-nears-live-news, pada 11 Oktober 2021 (21:19).

VOA Indonesia. 2021. "Peralihan Kekuasaan di Afghanistan, Kemunduran Strategis bagi India". Diakses dari https://www.voaindonesia.com/a/peraliha n-kekuasaan-di-afghanistan-kemunduranstrategis-bagi-india/6079895.html, pada 11 Oktober 2021 (21:46).

Wani, M. I., Mir, M. A., \& Akhter, K. 2017. "India's Economic Relations with Afghanistan: A Study in the Context of Trade \& Investment"pada Journal of Central Asian Studies, No 24.

Wong, Brian. 2021. "India and the Taliban: The Case for Constructive Engagement". Diakses dari https://thewire.in/diplomacy/india-talibanconstructive-engagement, pada 11 Oktober 2021 (21:49). 